\title{
LMX and OCB Civil Servants in Bandung, West Java
}

\author{
S.H. Senen ${ }^{1 ; *}$ M. Masharyono, Sumiyati ${ }^{3,}$ S. Khotijah ${ }^{4}$ \\ ${ }^{1}$ Universitas Pendidikan Indonesia \\ ${ }^{2}$ Universitas Pendidikan Indonesia \\ ${ }^{3}$ Universitas Pendidikan Indonesia \\ ${ }^{4}$ Universitas Pendidikan Indonesia \\ *Corresponding author.Email: syamsulhadisenen@upi.edu
}

\begin{abstract}
The era of bureaucratic reform is now carried out in various government agencies. Therefore, the role of OCB is considered vital, especially in the government sector. Problems about the achievement of OCB that have not been optimal were experienced by National Civil Service Agency (BKN) at Regional III Bandung. One of the efforts to increase the OCB of BKN employees at Regional Office III Bandung is by repairing LMX. This study employed a descriptive and verification analysis, while the method of the study was an explanatory survey involving 108 respondents. The analysis of the study used simple linear regression. The finding revealed that the picture of LMX was in a very high category. Then, the picture of OCB was in a very high category as well, especially in the courtesy dimension, and LMX gave an effect on OCB which was about 71.5\%. If an employee's behavior is grounded on OCB's behavior, then the organization's performance will be better and improve.
\end{abstract}

Keywords: Leader-Member Exchange (LMX), Organizational Citizenship Behavior (OCB).

\section{INTRODUCTION}

Human existence as human resources is important in the organizations because human resources support the organization through work, talent, creativity, encouragement, and real roles as can be seen in every organization [1]. Successful organizations need employees who not only act according to the written tasks in the job description but also employees who deliver the performance exceed the assigned tasks [2], or the individual displays an extra-role behavior.

The extra-roles behavior in organizations is known as an Organizational Citizenship Behavior (OCB) [3]. In the last two decades, OCB has become an interesting topic for researchers resulting in many studies regarding the concept of OCB, antecedents, correlation, and its consequences [4].

Organizations that are aware of the importance of OCB behavior are one of the success factors in assisting organizational development [5]. Many studies have focused on OCB problems in various sectors, such as the banking sector [6], transportation services [7], hospital [8], educational institution [9], state-owned enterprises (BUMN) [10], and public agency or government [11, 12].
OCB is often associated with organizations in government agencies, one of which is Civil Servants (PNS). The era of bureaucratic reform is currently carried out in various government agencies, then the role of $\mathrm{OCB}$ is considered vital and very decisive for organizations, especially in the government sector. Along with the development era, the state civil apparatus is confronted with government complexity tasks and its development, as well as the demands of a more varied and a qualified public services [13]. If employee behavior is grounded on OCB behavior, the organization's performance will be better and improve [13]. It is important to pay attention to the strengthening of $\mathrm{OCB}$ as a priority in achieving organizational goals, because OCB has a theoretical effect on organizational managerial processes [14].

One of the efforts that are able to overcome the OCB problem is the quality of Leader-Member Exchange (LMX) $[2,15]$. A good treatment to employees is able to create OCB behavior, so that they are able to sacrifice for the organization. Special treatment of positive leaders will increase employee's contributions to companies. [16]. 
Based on the background of the study above, the research questions of the study are as follows: 1) how is the picture of leader member exchange (LMX), 2) organizational citizenship behavior (OCB), and 3) the influence of LMX to OCB on employees.

\subsection{Leader-Member Exchange (LMX)}

According to [2], organizational behavior is a field of study that invests the influence of individuals, groups, and structures on behavior within organizations for the purpose of applying knowledge and increasing organizational effectiveness. Organizational behavior learns three determinants of behavior in organizations, namely individual, group, and structure. At the group level, group behavior is influenced by group dynamics, rules, and values adopted by the group [17].

One of the scopes at the group level is leadership [2]. According to [2], leadership is the ability to influence a group towards achieving a defined vision or goal. The role of the leader in a company is not only in terms of governing its employees, but also a good relationship between superiors and subordinates, which is needed to optimize human resources in a company. One concept of leadership in terms of relations between superiors and subordinates is usually called Leader-Member Exchange (LMX) [18].

Reference [2] explains that Leader- Member Exchange theory is a theory that supports the creation of leaders in groups and outside groups; subordinates in the group who will have a higher work rating, lower worker turnover rates, and higher job satisfaction. LMX dimension according to [19] is Affect, Loyalty, Contribution, Professional Respect.

\subsection{Organizational Citizenship Behavior (OCB)}

Organizational behavior can be analyzed through three determinants of behavior in organizations, namely individuals, groups, and structures [2]. Researchers have emphasized individual level outputs such as attitudes and satisfaction, task performance, citizenship behavior (Organizational Citizenship Behavior-OCB), and withdrawal behavior [2]. The level of individual analysis on the output variable is OCB.

Reference [20] defines OCB as a discretionary individual behavior, which does not directly and explicitly get an award from a formal reward system, and that as a whole (agrarian) increases the efficiency and effectiveness of organizational functions [19]. Meanwhile, according to [21], OCB is a form of informal behavior where people behave more than expected in contributing to the involved organizations. The OCB dimension according to [22] is altruism, courtesy, sportsmanship, conscientiousness, and civic virtue.
Based on the explanation of the influence of LMX on $\mathrm{OCB}$, the paradigm thinking is described in the framework in Figure 1.

\begin{tabular}{|l|l|}
\hline $\begin{array}{l}\text { LEADER MEMBER } \\
\text { EXCHANGE (LMX) }\end{array}$ & $\begin{array}{l}\text { ORGANIZATIONAL } \\
\text { CITIZENSHIP } \\
\text { BEHAVIOR (OCB) }\end{array}$ \\
1. Affect & $\begin{array}{l}\text { 1. Altruism } \\
\text { 2. Loyalty } \\
\text { 3. Contribution } \\
\text { 4. Professional }\end{array}$ \\
5. Respect & $\begin{array}{l}\text { 2. Courtesy } \\
\text { 3. Sportmanship } \\
\text { 4. Conscientiousness }\end{array}$ \\
\hline
\end{tabular}

Figure 1. Research paradigm

\section{METHODS}

The unit of analysis in the study was the employee of the National Civil Service Agency (BKN) at Regional III Bandung. The unit of analysis in this study was employees of the National Civil Service Agency (BKN) at Regional III Bandung in a period of less than one year, so that the data collection technique used was a crosssectional method. The sampling technique used in this study was stratified random sampling involving 108 employees of the National Civil Service Agency (BKN) at Regional III Bandung.

The data collection technique used was library studies and field research with questionnaires. Meanwhile, data analysis techniques used were descriptive and verification analysis. Data verification analysis used was simple linear regression with SPSS 22.0 for Windows software.

\section{RESULTS AND DISCUSSION}

\subsection{Descriptive Analysis}

\section{Leader-Member Exchange (LMX)}

Based on the results of the questionnaire, the description of LMX in the employees of the National Civil Service Agency (BKN) at Regional III Bandung is shown in Table 1.

TABLE I. RECAPITULATION OF LMX RESPONSES

\begin{tabular}{|l|l|l|l|c|}
\hline No & Dimension & Ideal score & Total Score & \% \\
\hline 1 & Affect & 2.160 & 1.955 & 90,51 \\
\hline 2 & Loyalty & 1.620 & 1.420 & 87,65 \\
\hline 3 & Contribution & 1.620 & 1.312 & 80,99 \\
\hline 4 & $\begin{array}{l}\text { Professional } \\
\text { Respect }\end{array}$ & 1.620 & 1.435 & 88,58 \\
\hline \multicolumn{2}{|l|}{ TOTAL } & $\mathbf{7 . 0 2 0}$ & $\mathbf{6 . 1 2 2}$ & $\mathbf{8 6 , 9 3}$ \\
\hline
\end{tabular}

Source: 2019 Data Processing Results (SPSS 22.0 for Windows Software)

Based on Table 1, the highest score on LMX is in affection dimension which scores 1,955 or $90.51 \%$, while the lowest score is in the contribution which scores 1,312 
or $80.99 \%$. Thus, it can be said that almost all respondents stated that LMX in employees of the National Civil Service Agency (BKN) at Regional III Bandung is in a very high category. Reference [23] states that if the superior and subordinate interactions have a high quality, then a superior will have a positive view of his subordinates so that his subordinates will feel that the superior provides a lot of support and motivation. This, of course, will increase the confidence and respect of subordinates to superiors so that they can work more than what is expected by their superiors.

\section{Organizational Citizenship Behavior (OCB)}

Based on the results of 108 questionnaires, there is an overview of OCB employees of the National Civil Service Agency (BKN) at Regional III Bandung as it can be seen in Table 2.

Table 2. Recapitulation of OCB Responses

\begin{tabular}{|l|l|l|l|l|}
\hline No & Dimension(s) & $\begin{array}{c}\text { Ideal } \\
\text { Score }\end{array}$ & $\begin{array}{c}\text { Total } \\
\text { Score }\end{array}$ & $\%$ \\
\hline 1 & Altruism & 2.700 & 2.232 & 82,67 \\
\hline 2 & Courtesy & 2.160 & 1.936 & 89,63 \\
\hline 3 & Sportmanship & 1.080 & 922 & 85,30 \\
\hline 4 & Coustienness & 2.160 & 1.845 & 85,42 \\
\hline 5 & Civic Virtue & 1.620 & 1.426 & 86,22 \\
\hline \multicolumn{2}{|l|}{ TOTAL } & $\mathbf{9 . 7 2 0}$ & $\mathbf{8 . 3 6 1}$ & $\mathbf{8 6 , 2 2}$ \\
\hline
\end{tabular}

Source: Data Processing Results 2019 (SPSS 22.0 for Windows Software)

Based on Table 2, the highest score of OCB is based on the results of the respondent's answers in the courtesy dimension which scores 1.936 or $89.63 \%$, while the lowest score is found in the altruism dimension which scores 2.232 or $82.67 \%$, It can be said that almost all respondents stated that $\mathrm{OCB}$ at the National Civil Service Agency (BKN) employee at Regional III Bandung was categorized in a very high category. Someone with a good OCB does the extra things like helping others or civilizing the overall performance of the organization [24].

\subsection{Verification Analysis}

This study consisted of independent variables namely LMX while for the dependent variable was OCB. In finding out the effect of LMX on OCB, a simple linear regression test was carried out. The form of a simple linear regression equation model in the study is can be seen in (1).

$$
\mathrm{Y}=\mathrm{a}+\mathrm{bX}
$$

Source: [25]

Where:

$$
\begin{array}{llll}
\mathrm{Y}=\text { OCB } & \mathrm{a} & =\text { Constant numbers } \\
\mathrm{X}=\mathrm{LMX} & \mathrm{b} & = & \text { Regression }
\end{array}
$$

Based on the results of data processing using the SPSS 22.0 for windows program, a simple linear regression coefficient is obtained as in Table 3.

Table 3. Regression coefficient

\begin{tabular}{|l|l|l|l|l|l|}
\hline \multicolumn{7}{|c|}{ Coefficients $^{\mathbf{a}}$} \\
\hline \multirow{2}{*}{ Model } & $\begin{array}{r}\text { Unstandardized } \\
\text { Coefficients }\end{array}$ & $\begin{array}{c}\text { Standardized } \\
\text { Coefficients }\end{array}$ & \multirow{2}{*}{$\boldsymbol{t}$ Sig. } \\
\cline { 2 - 5 } & $\boldsymbol{B}$ & Std. Error & \multicolumn{1}{|c|}{ Beta } & & \\
\hline Constant) & 40.048 & 8.740 & & 4.582 & .000 \\
\hline $\begin{array}{l}\text { Leader } \\
\text { Member } \\
\text { Exchange }\end{array}$ & .501 & .125 & .363 & 4.021 & .000 \\
\hline
\end{tabular}

Source: Data Processing Results 2019 (SPSS 22.0 for Windows Software)

Based on Table 3 in column B, there are constant values and simple linear regression coefficients for independent variables. These values can determine a simple linear regression model expressed in the form of equations as shown in (2).

$$
\mathrm{Y}=40,048+0,501 \mathrm{X}
$$

Equation (2) can be interpreted as follows:

- $\mathrm{a}=40,048$ it means that if the variable LMX is zero (0), then the variable OCB will be worth 40,048

- $\quad b 2=0,501$ it means that if LMX increases by one unit and the other variables are constant, then the OCB variable will increase by 0.501 units.

To find out the percentage effect of LMX on OCB, the coefficient of determination can be determined by the formula stated by [26] can be seen in (3).

$$
\mathrm{CD}=\mathrm{r}^{2} \times 100 \%
$$

Information:

- $\quad \mathrm{CD}=$ Coefficient Determination

- $\mathrm{r}=$ Correlation coefficient

- $100 \%=$ Constant

The effect of LMX on OCB can be seen from the results in Table 4.

Table 4. Partial Determination Coefficient

\begin{tabular}{|c|c|l|l|l|}
\hline \multicolumn{5}{|c|}{ Model Summary } \\
\hline Model & $\mathbf{R}$ & $\mathbf{R}$ Square & $\begin{array}{c}\text { Adjusted R } \\
\text { Square }\end{array}$ & $\begin{array}{c}\text { Std. Error of the } \\
\text { Estimate }\end{array}$ \\
\hline 1 & $.875^{\mathrm{a}}$ & .766 & .763 & 4.785 \\
\hline
\end{tabular}

Predictors: (Constant), Leader Member Exchange

Dependent Variable: Organizational Citizenship Behavior

Source: Data Processing Results 2019 (SPSS 22.0 for Windows Software)

$$
C D=(0,875)^{2} \times 100 \%
$$

$$
=71,5 \%
$$
coefficient 
The number of the correlation coefficient $(\mathrm{R})$ is 0.875. This means that the relationship between LMX and OCB is 0.875 . Based on the results of the calculation of the coefficient of determination for LMX with OCB is about $71.5 \%$. In other words, OCB is influenced by LMX by $71.5 \%$, while the remaining $28.5 \%$ is influenced by other factors that are not involved in this study, which can be a transformational leadership [8, 27], job satisfaction [28], perceived organizational support (POS) [29], motivation and organizational justice [30].

\subsection{Partial Hypothesis Test (T Test)}

The t-test basically shows how far the influence of one explanatory variable / independent individually in explaining the dependent variable. To find out the percentage effect of LMX on OCB using the SPSS 22.0 for Windows program, the following output is obtained in Table 5.

Table 5. Significance Value of T Test

\begin{tabular}{|l|c|l|l|l|l|}
\hline \multicolumn{7}{|c|}{ Coefficients $^{\mathrm{a}}$} \\
\hline \multirow{2}{*}{ Model } & $\begin{array}{c}\text { Unstandardized } \\
\text { Coefficients }\end{array}$ & $\begin{array}{c}\text { Standardized } \\
\text { Coefficients }\end{array}$ & \multirow{2}{*}{$\boldsymbol{t}$} & \multirow{2}{*}{ Sig. } \\
\cline { 2 - 4 } & $\boldsymbol{B}$ & Std. Error & Beta & & \\
\hline Constant) & 40.048 & 8.740 & & 4.582 & .000 \\
\hline $\begin{array}{l}\text { Leader } \\
\text { Member } \\
\text { Exchange }\end{array}$ & .501 & .125 & .363 & 4.021 & .000 \\
\hline
\end{tabular}

Dependent Variable: Organizational Citizenship Behavior

Source: Data Processing Results 2019 (SPSS 22.0 for Windows Software)

Based on Table 5, the acquisition of t-count is 4.021 for LMX. Significant level $(\alpha)$ is about $5 \%$, and degrees of freedom $\mathrm{df}=\mathrm{n}-\mathrm{k}=108-2=106$ obtained $\mathrm{t}$-table at about 4.00.

Due to $\mathrm{t}$-count $>\mathrm{t}$ table or $4.021>0.677$ then $\mathrm{Ha}$ is accepted, this means that LMX has an effect on OCB, with the magnitude of the influence of LMX on OCB by $71.5 \%$ and it is categorized in a strong category [25], while the remaining $28.5 \%$ is influenced by other factors that are not involved in this study, which can be a transformational leadership [8, 27], job satisfaction [28], percieved organizational support (POS) [29], motivation and organizational justice [30].

\section{CONCLUSIONS}

Based on the discussion above, several conclusions can be drawn: 1) The picture of LMX in National Civil Service Agency (BKN) at Regional III Bandung was in a very high category; 2) The picture of OCB in National Civil Service Agency (BKN) at Regional III Bandung was in a very high category; 3 ) There was an influence between LMX and OCB. This shows that the better the LMX, the higher the OCB employees of the National Civil Service Agency (BKN) at Regional III Bandung.
Based on the results of the study, it is suggested to improve LMX through contributions made by superiors or by the organization to employees in order to create a better leader-member exchange (LMX) so that it can simplify the effort to ignite organizational goals. In increasing the contribution in leader-member exchange (LMX), it can be done by involving employees on challenging tasks, providing training, and delegation on certain tasks. The level of contribution influences the number, difficulty, and importance of the assignment given and received by members because it shows the trustworthiness of the leader in the ability and willingness of the members to work on and to solve the difficult and important tasks [19].

\section{REFERENCES}

[1] Masharyono and S. H. Senen, "Analisis job performance pegawai honorer administrasi dengan kompetensi dan job characteristics dalam mendukung Universitas Pendidikan Indonesia mencapai Leading and Outstanding," Fokus Ekon., vol. 10, no. 2, pp. 119-137, 2015.

[2] S. P. Robin and T. A. Judge, Perilaku Organisasi, 16th ed. Jakarta: Salemba Empat, 2017.

[3] D. E. Purba and A. N. L. Seniati, "Pengaruh kepribadian dan komitmen organisasi terhadap organizational citizenship behavior," MAKARA, vol. 8, no. 3, pp. 105-111, 2004.

[4] J. Harvey, M. C. Bolino, and T. K. Kelemen, "Organizational citizenship behavior in the 21st century: How might going the extra mile look different at the start of the new millennium?," Emerald Insight, vol. 36, pp. 51-110, 2018.

[5] H. Ebrahimpour, A. Zahed, A. Khaleghkhah, and M. Bager, "Procedia social and a survey relation between organizational culture and organizational citizenship behavior," vol. 00, pp. 1920-1925, 2011.

[6] Apridar and M. Adamy, "The effect of job satisfaction and work motivation on organizational commitment and organizational citizenship behavior in BNI in the working area of Bank Indonesia Lhokseumawe," Emerald Insight, vol. 1, pp. 7-12, 2018.

[7] L. Maduningtias, "Pengaruh kepemimpinan transformasional dan motivasi kerja terhadap Organizational Citizenship Behavior (OCB) pada PT GMF Aero Asia," EDUKA J. Pendidikan, Huk. dan Bisnis, vol. 2, no. 4, 2017.

[8] D. Napitupulu, "Pegaruh kepemimpinan transformasional dan komitmen organisasi terhadap organizational citizenship behavior (Studi pada 
Perawat Rumah Sakit Puri Husada di Tembilahan)," JOM FISIP, vol. 5, no. 1, pp. 1-15, 2018.

[9] M. Claudia, "The influence of perceived organizational support, job satisfaction and organizational commitment toward organizational citizenship behavior (A Study of the permanent lecturers at University of Lambung Mangkurat, Banjarmasin)," J. Indones. Econ. Bus., vol. 33, no. 1, pp. 23-45, 2018.

[10] T. I. Sudarmo and U. D. A. Wibowo, "Pengaruh komitmen organisasional dan kepuasan kerja terhadap Organizational Citizenship Behavior (OCB) PT Telkom Mojokerto," PSYCHO IDEA, vol. 1, pp. 51-58, 2018.

[11] J. D. S. Bogar, D. Saerang, and H. Tawas, "Pengaruh gaya kepemimpinan transaksional dan gaya kepemimpinan transformasional terhadap komitmen organisasi dan organizational citizenship behavior (Studi pada Pegawai Kantor Sekretariat Dewan Kabupaten Siau-Taguladang-Baro)," J. EMBA, vol. 6, no. 1, pp. 231-240, 2018.

[12]Y. Oemar, "Pengaruh budaya organisasi, kemampuan kerja dan komitmen organisasi terhadap Organizational Citizenhsip Behavior (OCB) pegawai pada BAPPEDA Kota Pekanbaru," J. Apl. Manaj., vol. 11, no. 66, pp. 65-76, 2013.

[13]H. Hermanto, M. Heriyanto, and O. Karneli, "Kepuasan Kerja, komitmen organisasi, kepemimpinan, budaya organisasi dan Organizational Citizenship Behavior (CB)," J. Ilmu Adm. Negara, vol. 14, no. 3, pp. 324-333, 2017.

[14] M. Zayas-Ortiz, E. Rosario, E. Marquez, and P.C. Gruneiro, "Relationship between organizational commitments and organizational citizenship behaviour in a sample of private banking employees," International J. of Sociology and Social Policy, 2015.

[15] D. W. Organ, “Organizational Citizenship Behavior: Recent Trends and Developments," Annu. Rev. Organ. Psychol. Organ. Behav., vol. 80, no. 1, pp. 295-306, 2017.

[16] Peter Northouse, Kepemimpinan: Teori dan Praktik, Keenam. Jakarta: Indeks, 2017.

[17] V. Rivai, M. D. Hadad, and M. Ramly, Kepemimpinan dan Perilaku Organisasi. Depok: PT RajaGrafindo Persada, 2017.

[18]M. Ilham and J. Herawati, "Pengaruh Leader Member Exchange (LMX) dan motivasi terhadap Organizational Citizenship Behavior (OCB) pada PT. Bank Central Asia Kantor Cabang Utama
Yogyakarta,” J. Majemen Dewantara, vol. 1, no. 2, pp. 44-55, 2017.

[19] R. C. Liden and J. M. Maslyn, "Multidimensionality of leader-member exchange: An empirical assessment through scale development," J. Manage., vol. 24, pp. 43-72, 1988.

[20]C. A. O. D. W. N. J. P. Smith, D. W. Organ, and J. P. Near, "Organizational citizenship behavior: Its nature and antecedents," J. of Applied Psychology, vol. 68 , no. $4,653,1983$.

[21]J. Greenberg, Organizational justice: The dynamics of fairness in the workplace. 2011.

[22] D.W. Organ, Organizational Citizenship Behavior: The Good Soldier Syndrome. Lexington Books/DC Heath and Com, 1988.

[23] R. E. Riggio, Introduction to Industrial Psychology, 5th Editio. New Jersey: Pearson Education, 2009.

[24] J. R. Schermerhorn, R. N. Osborn, M. Uhl-Bien, and J. G. Hunt, Organizational Behavior, 11 th ed. Wiley, 2012.

[25] Sugiyono, Metode Penelitian Kuantitatif, Kualitatif, dan R\&D. Bandung: Alfabeta, 2017.

[26]Riduwan, Cara Menggunakan dan Memakai Analisis Jalur (Path Analysis). Bandung: Alfabeta, 2013.

[27]L. Ocampo et al., "A historical review of the development of Organizational Citizenship Behavior (OCB) and its implications for the twentyfirst century," Emerald Insight, vol. 47, no. 4, pp. 821-862, 2018.

[28]D. Arianto, "Pengaruh kepuasan kerja terhadap kinerja karyawan melalui organizational citizenship behavior sebagai variabel intervening (Studi pada Staf PT Kepuh Kencana Arum Mojokerto),” J. Ilmu Manaj., vol. 5, 2017.

[29] K. Na-Nan, J. Joungtrakul, and A. Dhienhirun, “The influence of perceived organizational support and work adjustment on the employee performance of expatriate teachers in Thailand," Mod. Appl. Sci., vol. 12, no. 3, p. 105, 2018.

[30] W. A. Santika and I. M. A. Wibawa, "Pengaruh iklim organisasi, motivasi kerja dan keadilan organisasi terhadap Organizational Citizenship Behavior (OCB)," E-J. Manaj. Unud, vol. 6, no. 9, pp. 4659-4688, 2017. 